\title{
Innovatiivisia rehukasveja nautakarjatiloille
}

\author{
Essi Saarinen ${ }^{1)}$, Perttu Virkajärvi ${ }^{2)}$, Arto Huuskonen ${ }^{1)}$, Maarit Hyrkäs ${ }^{2)}$, Markku Niskanen ${ }^{3)}$, Maiju \\ Pesonen $^{1)}$ ja Raija Suomela ${ }^{1)}$ \\ ${ }^{1)}$ Maa- ja elintarviketalouden tutkimuskeskus, Kotieläintuotannon tutkimus, Tutkimusasemantie 15, \\ 92400 Ruukki, essi.saarinen@mtt.fi, arto.huuskonen@mtt.fi, maiju.pesonen@mtt.fi. \\ raija.suomela@mtt.fi \\ ${ }^{2)}$ Maa- ja elintarviketalouden tutkimuskeskus, Kotieläintuotannon tutkimus, Halolantie 31A, 71750 \\ Maaninka,perttu.virkajarvi@mtt.fi,maarit.hyrkas@mtt.fi \\ ${ }^{3)}$ Maa- ja elintarviketalouden tutkimuskeskus, Kasvintuotannon tutkimus, Alapääntie 104, 61400 Ylis- \\ taro, markku.niskanen@mtt.fi
}

\section{Tiivistelmä}

Ilmaston lämpenemisen seurauksena suomalaisilla nautakarjatiloilla saattaa jatkossa olla mahdollista viljellä uusia rehukasveja. Ostotypen korkeat kustannukset ja lisääntynyt kiinnostus kotoisen valkuaisrehun tuotantoon ovat luoneet tarpeen tutkia typensitojakasvien käyttöä kokoviljasäilörehuna. Emolehmätuotannossa laidunkauden pidentäminen toisi kustannussäästöjä eläinten ruokintaan. MTT:n toteuttamassa InnoNauta Kehitys -hankkeessa testattiin rehukaalin, -rapsin ja -juurikkaan sekä hirssin sadontuottokykyä Maaningan ja Ruukin toimipisteissä. Kokoviljasäilörehuksi korjattiin kahta härkäpapu-vehnä -seosta. Myös sini- ja valkolupiinin satopotentiaalia testattiin.

Tutkimuksessa haettiin innovatiivisia rehukasveja, joista rehukaalta, -rapsia, -juurikasta, lupiineja ja hirssiä kasvatettiin havaintoruuduilla (2 toistoa). Härkäpapu-vehnä (50:50, 70:30) -seoksia pidettiin potentiaalisimpana, joten niitä kasvatettiin kolmessa kerranteessa. Kokeet toteutettiin MTT Maaningan ja Ruukin toimipisteissä vuosina 2010 ja 2011. Koeruuduilta määritettiin hehtaarisato sekä rehujen kemiallinen koostumus ja rehuarvot. Rehujuurikkaalta määritettiin lisäksi kivennäiskoostumus ja tärkkelys etanoliuutolla.

Rehukasvivalikoimaa laajentamalla olisi mahdollista pidentää laidunkautta, sillä rehurapsi, rehukaali ja rehujuurikas menestyivät hyvin Pohjois-Savossa ja -Pohjanmaalla. Rehukaalin sadontuottokyky vaihteli kokeessa runsaasti ollen 3 300-10 900 ka kg/ha. Rehurapsi tuotti satoa rehukaalia tasaisemmin. Hyvissä kasvuolosuhteissa kasvi ylsi 7 600-10 800 ka kg hehtaarisatoihin. Rehujuurikkaan kokonaissadontuottokyky (naatit+juuret) oli 11 300-15 800 ka kg/ha. Naattien osuus kokonaismassasta oli hieman yli kolmannes. Rehukaali, -rapsi ja -juurikas kestivät hyvin pakkasta ja ne korjattiin vasta syys-lokakuussa. Viivästetyn laidunruokinnan haasteena Suomessa on kuitenkin peltojen erittäin kosteat olosuhteet varsinkin sateisena syksynä. Hirssit osoittautuivat hallanaroiksi eikä niiden viljelyä voi suositella Keski- ja Pohjois-Suomen olosuhteissa

Härkäpapu-vehnä -seoksessa sääolojen lisäksi lajikevalinta ja korjuuajankohta vaikuttivat tulokseen, mutta erot eivät olleet tilastollisesti merkitseviä. Seokset osoittautuivat varmoiksi sadontuottajiksi, keskimäärin niistä saatiin 8600 ka kg hehtaarilta. Kontu -härkäpapu -Trappe -vehnäseos, joka kylvettiin 70:30 siemensuhteella (70 \% härkäpavun täystiheydestä / $30 \%$ vehnän täystiheydestä,) tuotti keskimäärin vain noin $200 \mathrm{ka}$ kg enemmän satoa hehtaarilta, kuin 50:50 -seossuhteessa kylvetty seos. Kokeessa ei saatu merkitsevää eroa eri kylvömääräsuhteilla kylvettyjen koejäsenten kuivaainesatoihin.

Härkäpapu-vehnä -kasvustojen energia-arvot on laskettu rehutaulukon perusteella. Maaningalla sadoista saatiin yli $70000 \mathrm{MJ} / \mathrm{ha}$, Ruukissa päästiin vuonna 2010 yli $80000 \mathrm{MJ} / \mathrm{ha}$ energiasatoon ja 2011 jopa yli 100000 MJ/ha energiasatoon. Luvut ovat suuntaa antavia, sillä käytännön kokemuksien perusteella eläimet ovat lypsäneet hyvin härkäpapu-vilja -säilörehulla ja tuntuma on, että härkäpapu seosten sulavuudet ja siten myös energia-arvot voisivat olla jopa laskennallisia arvoja korkeammat. Tällä hetkellä on vaikea arvioida seosten tarkkoja energia-arvoja, koska härkäpapusäilörehun sulavuuskokeita ei ole tehty pohjoismaissa eikä rehulaboratorioiden menetelmiä ole voitu kalibroida todelliseen in vivo -sulavuuteen.

Asiasanat: rehuntuotanto, rehukasvit, härkäpapu, rehukaali, rehurapsi, rehujuurikas, hirssi, lupiinit 


\section{Johdanto}

Ilmaston lämpenemisen seurauksena suomalaisilla nautakarjatiloilla saattaa jatkossa olla mahdollista viljellä uusia rehukasveja. Ostotypen korkeat kustannukset ja lisääntynyt kiinnostus kotoisen valkuaisrehun tuotantoon ovat luoneet tarpeen tutkia typensitojakasvien käyttöä kokoviljasäilörehuna. Puhtaista viljakasvustoista tehdyn kokoviljasäilörehun heikkoutena nurmisäilörehuun verrattuna on alhaisempi energia- ja valkuaispitoisuus. Säilörehun energiapitoisuus on riippuvainen rehun sulavuudesta (Darvo). Kokoviljasäilörehun sulavuus riippuu ennen kaikkea tähkän ja korren osuuksista kasvustossa sekä jyvien osuudesta korjattavassa rehumassassa (Joki-Tokola 2002, 2003a,b). Käyttämällä palkokasveja viljojen kanssa seoksina voidaan pyrkiä parantamaan kokoviljasäilörehun energia- ja ennen kaikkea valkuaispitoisuutta (Nykänen ym. 2010). Rehu- ja ruisvirnan (Lehto \& Joki-Tokola 1999, Joki-Tokola ym. 2002a,b, Manninen ym. 2004) sekä herneen (Kiljala ym. 2004, Nykänen \& Jauhiainen 2010) käytöstä kokoviljasäilörehuseoksissa on olemassa jonkin verran kotimaisia tutkimustuloksia. Sen sijaan härkäpapuseoksia (Vicia faba) on meillä tutkittu vähemmän. Viime vuosina maatiloilla on kuitenkin ilmennyt kasvavaa kiinnostusta myös vilja-härkäpapu -seosten viljelyyn ja ruokintakäyttöön.

Vilja-palkokasvi -seoksia voidaan käyttää nurmisäilörehun tapaan säilörehuna, mutta myös kasvustojen laiduntaminen on mahdollista. Erityisesti emolehmätuotannossa laidunkauden pidentäminen toisi kustannussäästöjä eläinten ruokintaan. Laidunkauden pidentämiseen on mahdollista käyttää myös esimerkiksi rehukaalia (Brassica oleracea) ja rehurapsia (Brassica napus), joita käytetään muiden ristikukkaisten lehti- ja juurikaskasvien tavoin lauhkean ilmaston alueella yleisesti pidentämään nautojen ja lampaiden laidunkautta.

MTT:n toteuttamassa InnoNauta Kehitys -hankkeessa testattiin rehukaalin, -rapsin ja juurikkaan sekä hirssin sadontuottokykyä Maaningan ja Ruukin toimipisteissä. Kokoviljasäilörehuksi korjattiin kahta härkäpapu-vehnä seosta. Myös sini- (Lupinus angustifolius) ja valkolupiinin (Lupinus albus) satopotentiaalia testattiin.

\section{Aineisto ja menetelmät}

Tutkimuksessa testattiin innovatiivisia rehukasveja, joista rehukaalta, -rapsia, -juurikasta, lupiineja ja hirssiä kasvatettiin havaintoruuduilla (2 toistoa). Härkäpapu-vehnä (50:50, 70:30) -seoksia pidettiin potentiaalisimpana, joten niitä kasvatettiin kolmessa kerranteessa. Kokeet toteutettiin MTT Maaningan ja Ruukin toimipisteissä vuosina 2010 ja 2011. Kylvömäärät ja lannoitus valittiin olemassa olevien suositusten mukaan (Taulukko1).

Koeruuduilta määritettiin kuiva-ainesato sekä rehujen kemiallinen koostumus ja rehuarvot (raakavalkuainen (Leco), tuhka, orgaanisen aineen sellulaasiliukoisuus, NDF-kuitu ja D-arvo). Rehujuurikkaalta määritettiin lisäksi kivennäiskoostumus (kalsium, magnesium, fosfori, rikki, kalium, natrium, rauta, kupari, sinkki ja mangaani) ja tärkkelys etanoliuutolla.

Kokeen tulokset analysoitiin tilastollisesti käyttäen SAS 9.2.:n Mixed-proseduuria. Ensimmäisessä vaiheessa käytettiin mallia, jossa kiinteinä muuttujina olivat kasvilaji, vuosi, paikkakunta ja näiden kaikki yhdysvaikutukset sekä satunnaismuuttujana kerranne paikkakunta*vuosi-vaikutuksen sisällä. Tällöin mallista jätettiin pois sini- ja valkolupiini sekä härkäpapu Fuego, koska niiltä oli tuloksia vain yhdeltä vuodelta. Koska kasvin, vuoden ja koepaikan yhdysvaikutukset olivat voimakkaita, analysoitiin paikkakunnat ja vuodet erikseen, jolloin mallissa oli kasvilaji kiinteänä muuttujana ja kerranne satunnaismuuttujana. Satotulosten laskennassa käytettiin rehujuurikkaan kokonaissatoa, mutta laatumuuttujien ja kuiva-ainepitoisuuden kohdalla naatit ja juuret käsiteltiin omina koejäseninään. Parivertailut tehtiin Tukey-Kramerin testillä.

\section{Tulokset ja tulosten tarkastelu}

Vuodet 2010 ja 2011 olivat molemmilla koepaikoilla keskimääräistä lämpimämmät (Taulukko 2). Erityisesti vuoden 2010 heinäkuu oli poikkeuksellisen kuiva ja lämmin Maaningalla.

Eri viljelykasvit poikkesivat toisistaan odotusten mukaisesti (Kuva 1, Taulukko 3). Kaikkien satomuuttujien tapauksessa havaitut erot riippuivat sekä vuodesta että koepaikasta ja toisinaan myös kasvi × vuosi × koepaikka -yhdysvaikutuskin oli merkittävä, joten tulokset esitetään paikkakunnat ja vuodet erikseen. 


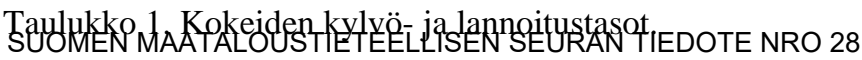

\begin{tabular}{|c|c|c|c|c|c|c|c|c|c|}
\hline & Lajike & Siemenmäärä & & Riviväli & Kylvösyvyys & $\underset{\text { kg/ha }}{\mathbf{N}}$ & $\underset{\text { kg/ha }}{P}$ & $\underset{\mathbf{k g} / \mathbf{h}}{\mathrm{K}}$ & Huom \\
\hline Hirssi & & $5 \mathrm{~kg} / \mathrm{ha}$ & & $25 \mathrm{~cm}$ & $2-3 \mathrm{~cm}$ & 100 & 15 & 70 & \\
\hline $\begin{array}{l}\text { Härkäpapu/vehnä } \\
\text { 70-30 }\end{array}$ & Kontu/Trappe & $\begin{array}{l}\text { papu: } \\
49 \mathrm{kpl} / \mathrm{m} 2\end{array}$ & $\begin{array}{l}\text { vehnä: } \\
195 \\
\mathrm{kpl} / \mathrm{m} 2\end{array}$ & $12,5 \mathrm{~cm}$. & $7-8 \mathrm{~cm}$ & 50 & 15 & 30 & \\
\hline $\begin{array}{l}\text { Härkäpapu/vehnä } \\
50-50\end{array}$ & Kontu/Trappe & $\begin{array}{l}\text { papu: } \\
35 \mathrm{kpl} / \mathrm{m} 2\end{array}$ & $\begin{array}{l}\text { vehnä: } \\
325 \\
\text { kpl/m2 }\end{array}$ & & & 50 & 15 & 30 & \\
\hline $\begin{array}{l}\text { Härkäpapu/vehnä } \\
\text { 70:30 }\end{array}$ & $\begin{array}{l}\text { Fuego/kevät- } \\
\text { vehnä }\end{array}$ & $\begin{array}{l}\text { papu } \\
49 \mathrm{kpl} / \mathrm{m} 2 .\end{array}$ & $\begin{array}{l}\text { vehnä } \\
195 \\
\mathrm{kpl} / \mathrm{m} 2\end{array}$ & & & 50 & 15 & 30 & $\begin{array}{l}\text { vain } \\
2011\end{array}$ \\
\hline Valkolupiini & & $\begin{array}{l}\text { valkolupiini } \\
45 \mathrm{kpl} / \mathrm{m} 2 . \\
\text { Vehnä } 200 \\
\text { kpl/m2 }\end{array}$ & & $12,5 \mathrm{~cm}$ & $5 \mathrm{~cm}$ & 30 & $\begin{array}{l}\text { sama } \\
\text { kuin } \\
\text { vilja }\end{array}$ & $\begin{array}{l}\text { sama } \\
\text { kuin } \\
\text { vilja }\end{array}$ & $\begin{array}{l}\text { vain } \\
2011\end{array}$ \\
\hline Sinilupiini & Ludic & & & & & 30 & $"$ & $"$ & $\begin{array}{l}\text { vain } \\
2010\end{array}$ \\
\hline Rehukaali & Sonat & $5-8 \mathrm{~kg}$ & & $\begin{array}{l}25-50 \\
\mathrm{~cm}\end{array}$ & n. $2 \mathrm{~cm}$ & 100 & 70 & 170 & \\
\hline Rehujuurikas & & 15 cm välein & & 47,5 & $3 \mathrm{~cm}$ & 140 & $\begin{array}{c}43 \\
\text { (vält) }\end{array}$ & $\begin{array}{c}220 \\
\text { (vält) }\end{array}$ & \\
\hline Rehurapsi & & $8-11 \mathrm{~kg} / \mathrm{ha}$ & & $\begin{array}{l}25-50 \\
\mathrm{~cm}\end{array}$ & n. $2 \mathrm{~cm}$ & 100 & $10 \mathrm{~kg}$ & $60 \mathrm{~kg}$ & \\
\hline
\end{tabular}

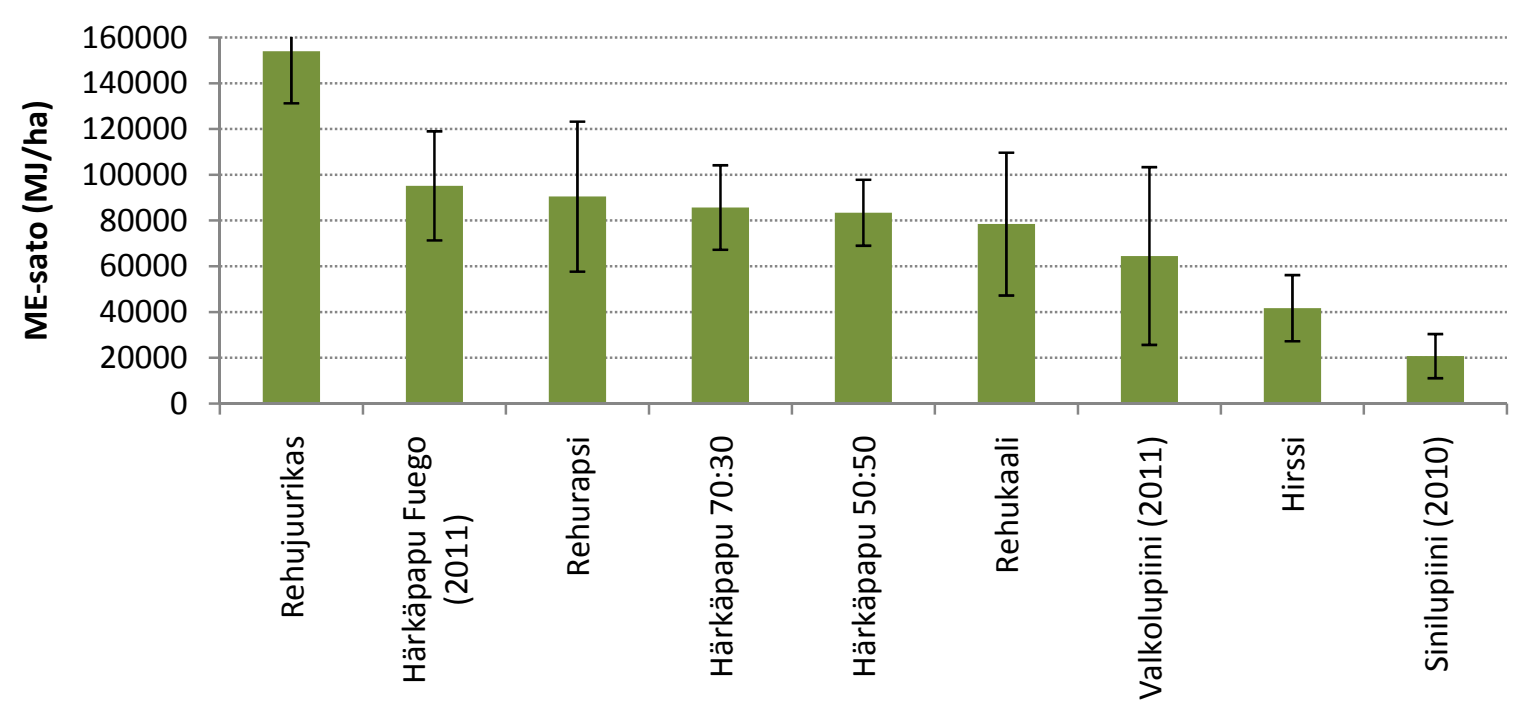

Kuva 1. Innovatiivisten rehukasvien energiasato (MJ/ha). Laskennassa ovat mukana Ruukin ja Maaningan tulokset vuosilta 2010 ja 2011. Virhepalkit kuvaavat aineiston keskihajonnan.

Taulukko 2. Koepaikkojen kuukausikohtaiset keskilämpötilat ja sademärät vuosina 2010 ja 2011 sekä pitkän aikavälin keskiarvo (1971-2000)

\begin{tabular}{|c|c|c|c|c|c|c|c|c|}
\hline & \multicolumn{4}{|c|}{ Keskilämpötila, ${ }^{\circ} \mathrm{C}$} & \multicolumn{4}{|c|}{ Sademäärä, mm } \\
\hline & \multicolumn{2}{|c|}{2010} & \multicolumn{2}{|c|}{2011} & \multicolumn{2}{|c|}{2010} & \multicolumn{2}{|c|}{2011} \\
\hline & Maaninka & Ruukki & Maaninka & Ruukki & Maaninka & Ruukki & Maaninka & Ruukki \\
\hline Touko & 11.4 & 10.9 & 9.6 & 8.6 & 54 & 24 & 47 & 29 \\
\hline Kesä & 13.4 & 12.1 & 16.3 & 15.7 & 74 & 35 & 48 & 53 \\
\hline Heinä & 21.5 & 18.6 & 19.3 & 18 & 10 & 59 & 142 & 64 \\
\hline Elo & 15.9 & 13.6 & 15.2 & 14.3 & 58 & 72 & 84 & 86 \\
\hline Syys & 10.1 & 8.9 & 11.3 & 10.9 & 60 & 65 & 67 & 81 \\
\hline Loka & $-*$ & - * & 5.5 & 5.5 & - * & - * & 43 & 59 \\
\hline $\begin{array}{l}\text { Touko- } \\
\text { Syys }\end{array}$ & 14.5 & 12.8 & 12.9 & 12.2 & 256 & 255 & 429 & 313 \\
\hline 1971-2000 & 12.4 & 11.4 & 12.4 & 11.4 & 321 & 277 & 321 & 277 \\
\hline
\end{tabular}

*Vuonna 2010 kasvit korjattiin jo syyskuussa ja siksi lokakuun tietoja ei mainita 
Taulukko 3. Eri viljelykasvien satomuuttujien varianssianalyysin merkitsevyydet. Molemmat koepaikat ja molemmat vuodet. $\mathrm{N}$ = havaintojen lukumäärä.

\begin{tabular}{lcccccc} 
& Ka $\%$ & D-arvo & NDF & Rv & Ka-sato & ME-sato \\
& $\%$ & g/kg ka & g/kg ka & g/kg ka & kg ka/ha & MJ/ha \\
\hline n & 64 & 48 & 63 & 64 & 56 & 56 \\
Kasvi & $* * *$ & $* * *$ & $* * *$ & $* * *$ & $* * *$ & $* * *$ \\
Kuosi & $* * *$ & $* * *$ & $*$ & & $*$ & $* *$ \\
Kasvi*Koepaikka & $*$ & & & $* *$ & $* * *$ & $* *$ \\
Kasvi*Vuosi & $* * *$ & $* * *$ & $* * *$ & $* * *$ & $* * *$ & $* * *$ \\
Vuosi*Koepaikka & $* * *$ & $* *$ & $* * *$ & $* * *$ & $* * *$ & $* * *$ \\
Vuosi $*$ Koepaikka* Kasvi & $* * *$ & $*$ & $*$ & $*$ & 0 & $* * *$ \\
\hline
\end{tabular}

Tilastolliset merkitsevyydet $* * *(\mathrm{P}<0,001)$, **(P<0,01), *(P<0,05) ja o $(\mathrm{P}<0,10)$.

\section{Rehurapsi ja rehukaali}

Rehukasvivalikoimaa laajentamalla olisi mahdollista pidentää laidunkautta, sillä rehukaali, rehurapsi ja rehujuurikas kestivät hyvin pakkasta ja ne korjattiin vasta syys-lokakuussa. Rehukaalin sadontuottokyky vaihteli kokeessa runsaasti ollen 3 300-10 900 ka kg/ha (Taulukko 4.). Rehurapsi tuotti rehukaalia tasaisemmin satoa, joka oli myös paremmin sulavaa. Hyvissä kasvuolosuhteissa kasvi ylsi 7 600-10 800 ka kg/ha satotasoihin. Maaningalla rehurapsi kärsi kuivista oloista vuonna 2010 ja tuotti vain noin 3500 kuiva-ainekilon sadon. Rehurapsista saatiin korkeat energiasadot hehtaarilta, keskimäärin yli $90000 \mathrm{MJ} / \mathrm{ha}$.

Rehukaalin ja -rapsin tyyppisten ristikukkaisten rehukasvien pääasiallinen hyödyntämistapa on laiduntaminen (Bartholomew 2011). Haluttaessa korjuu voidaan tehdä myös tavanomaisilla pystykasvustosta korjaavilla koneilla. Ristikukkaisia on tarkoitus laiduntaa viileän ilmaston oloissa kasvukauden lopulla, kun nurmien laatu huononee ja kasvu on olematonta tai päättynyt. Mikäli laidunnetaan jo tätä aiemmin, ristikukkaisilla on jonkin verran uudelleenkasvukykyä. Lämpimissä ilmastoissa tätä ominaisuutta hyödynnetään yleisesti. Tällöin rehurapsia laidunnetaan useasti ja rehukaalia käytetään talvilaitumena ympärivuotiseen laiduntamiseen (Bartholomew 2011). Suomen olosuhteissa viivästetyn laidunruokinnan haasteena ovat ennen kaikkea peltojen erittäin kosteat olosuhteet varsinkin sateisena syksynä.

\section{Rehujuurikas}

Rehujuurikkaan kokonaissadontuottokyky (naatit+juuret) oli 11 300-15 800 ka kg/ha. Naattien osuus kokonaismassasta oli hieman yli kolmannes. Myös kasvin energiasato oli korkea, kokeessa keskimäärin yli $150000 \mathrm{MJ} / \mathrm{ha}$. Rehujuurikkaan juuri lukeutuu sisältönsä puolesta energiarehuksi ja on verrattavissa perunaan, joka sisältää hieman rehujuurikasta enemmän tärkkelystä (MTT 2011). Energiarehuna rehujuurikas korvaa perinteisessä annoksessa väkirehua, kuitenkin vain rajallisesti, sillä siinä on valkuaisaineita vielä vähemmän kuin viljoissa.

Rehujuurikas on nykypäivänä ns. uusvanha rehukasvi. Viime vuosisadan puolivälissä se oli eläinrehujen valtakasvi Keski-Euroopassa, mutta tämän vuosituhannen alussa se on enää hyvin pienimuotoisesti käytössä, koska kasvi on ollut työläs viljellä ja korjata. Yksi mahdollisuus rehujuurikkaan hyödyntämiseen voisi olla laidunnus, sillä käytännön kokemusten perusteella sekä rehujuurikkaan juuri että naatti ovat maistuvaa rehua ja laiduntavat eläimet kaivavat myös juuret maasta. Suomen olosuhteissa laidunruokinnan haasteena ovat kuitenkin syksyn kosteat olosuhteet.

\section{Hirssi}

Vuonna 2010 kokeissa oli mukana hirssilaji Pearl millet (Pennisetum glaucum), lajikkeena Perlé Sucré Itä-Kanadasta. Se osoittautui erittäin hallanaraksi eikä sen viljelyä voi suositella Keski- ja PohjoisSuomen olosuhteissa. Vuonna 2011 kokeissa oli hallaa kestävämpi Proso millet -laji (Panicum miliaceum), jota viljellään Keski-Kanadassa. Kokoviljasadot jäivät Pearl millet -lajilla kahdesta neljään tuhanteen kuiva-ainekiloon hehtaarilta. Proso millet -tuotti noin 4 000-6 000 ka kg sadon hehtaarilta. 
Taulukko 4. Eri viljelykasvien satomuuttujien keskiarvot Maaningalla ja Ruukissa vuosina 2010 ja 2011. Varianssianalyysien keskiarvot, keskivirheet ja merkitsevyys. Maaninka 2010

\begin{tabular}{|c|c|c|c|c|c|c|c|c|c|c|c|c|c|c|}
\hline Nro & Kasvi & $\begin{array}{c}\text { KA } \\
\% \\
\end{array}$ & $\begin{array}{l}\text { D-arvo } \\
\text { g/kg ka }\end{array}$ & $\begin{array}{c}\text { NDF } \\
\text { g/kg ka }\end{array}$ & $\begin{array}{c}\text { RV } \\
\text { g/kg ka } \\
\end{array}$ & $\begin{array}{l}\text { Ka-sato } \\
\mathrm{kg} \mathrm{ka} / \mathrm{ha} \\
\end{array}$ & $\begin{array}{c}\text { ME-sato } \\
\text { MJ/ha }\end{array}$ & Nro & $\begin{array}{c}\text { KA } \\
\% \\
\end{array}$ & $\begin{array}{l}\text { D-arvo } \\
\text { g/kg ka }\end{array}$ & $\begin{array}{c}\text { NDF } \\
\text { g/kg ka }\end{array}$ & $\begin{array}{c}\text { RV } \\
\text { g/kg ka }\end{array}$ & $\begin{array}{l}\text { Ka-sato } \\
\mathrm{kg} \mathrm{ka/ha}\end{array}$ & $\begin{array}{c}\text { ME-sato } \\
\text { MJ/ha }\end{array}$ \\
\hline 1 & \multirow{2}{*}{$\begin{array}{l}\text { Rehukaali } \\
\text { Rehujuurikas }\end{array}$} & $16.1 \mathrm{ab}$ & $686 \mathrm{a}$ & 305 a & $104 \mathrm{a}$ & 6878 a & 73189 a & 1 & $11.6 \mathrm{a}$ & 734 a & $229 \mathrm{ab}$ & 186 a & 3283 a & 36839 a \\
\hline 2 & & . & . & . & . & $11837 \mathrm{~b}$ & $143365 \mathrm{~b}$ & 2 & . & . & . & . & $11253 \mathrm{~b}$ & $137475 \mathrm{~b}$ \\
\hline & \multirow{2}{*}{$\begin{array}{l}\text { naatit } \\
\text { juuret }\end{array}$} & $12.3 \mathrm{a}$ & $650 *$ & $211 b$ & $152 \mathrm{~b}$ & 3733 & 38819 & & $9.2 \mathrm{~b}$ & $650 *$ & $190 \mathrm{a}$ & 131 bcd & 3076 & 31989 \\
\hline & & $14.7 \mathrm{ab}$ & $820 *$ & 138 c & $64 \mathrm{c}$ & 8104 & 104546 & & 15.3 c & $820 *$ & $105 \mathrm{c}$ & $92 \mathrm{e}$ & 8177 & 105486 \\
\hline 3 & \multirow{5}{*}{$\begin{array}{l}\text { Hirssi } \\
\text { Rehurapsi } \\
\text { Härkäpapu 70:30 } \\
\text { Härkäpapu 50:50 } \\
\text { Sinilupiini ** }\end{array}$} & $17.2 \mathrm{~b}$ & 685 a & $604 \mathrm{~d}$ & $152 \mathrm{~b}$ & 2194 c & 23415 c & 3 & 20.7 de & 591 bc & $592 \mathrm{~d}$ & 103 be & 6359 c & 57772 c \\
\hline 4 & & $16.7 \mathrm{~b}$ & $786 \mathrm{~b}$ & $201 \mathrm{~b}$ & 126 a & $3499 \mathrm{~d}$ & $42576 \mathrm{~d}$ & 4 & 13.9 c & 736 a & $265 b$ & 125 bc & 7584 cd & 85935 d \\
\hline 5 & & $38.8 \mathrm{c}$ & $674 \mathrm{a}$ & 439 e & $127 \mathrm{a}$ & 6760 a & 70584 a & 5 & 19.9 eg & $606 \mathrm{~b}$ & $481 \mathrm{e}$ & $167 \mathrm{af}$ & $7754 \mathrm{~cd}$ & 72690 cd \\
\hline 6 & & $38.4 \mathrm{c}$ & 679 a & $440 \mathrm{e}$ & $110 \mathrm{a}$ & 7229 a & 76077 a & 6 & $21.6 \mathrm{df}$ & 596 bc & 515 e & $153 \mathrm{cdf}$ & 7618 cd & $70462 \mathrm{~cd}$ \\
\hline \multirow[t]{5}{*}{7} & & $92.6 \mathrm{~d}$ & $875 \mathrm{c}$ & $248 \mathrm{~b}$ & $304 d$ & 918 e & 12452 c & 7 & $22.7 \mathrm{f}$ & 559 c & $565 d$ & 101 be & 3710 a & 31748 a \\
\hline & & & & & & & & 8 & $18.9 \mathrm{~g}$ & $593 \mathrm{bc}$ & $493 \mathrm{e}$ & 158 adf & $8130 \mathrm{~d}$ & $74746 \mathrm{~d}$ \\
\hline & SEM & 1,24 & 9,5 & 16,6 & 8,9 & 368,4 & 4314,0 & & 0,82 & 15,7 & 15,1 & 10,6 & 511,3 & 5565,2 \\
\hline & Til. merkitsevyys & $* * *$ & $* * *$ & $* * *$ & $* * *$ & $* * *$ & $* * *$ & & $* * *$ & $* * *$ & $* * *$ & $* * *$ & $* * *$ & $* * *$ \\
\hline & \multicolumn{7}{|l|}{ Ruukki 2010} & \multicolumn{4}{|c|}{ Ruukki 2010} & & & \\
\hline 1 & Rehukaali & $16.0 \mathrm{a}$ & $674 \mathrm{a}$ & $308 \mathrm{a}$ & $122 \mathrm{a}$ & $10866 \mathrm{a}$ & 113495 a & 1 & $16.2 \mathrm{a}$ & $667 \mathrm{a}$ & $312 \mathrm{a}$ & 122 abd & $8706 \mathrm{a}$ & 89561 a \\
\hline \multirow[t]{3}{*}{2} & Rehujuurikas & 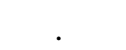 & . & . & . & $15796 \mathrm{~b}$ & 186914 b & 2 & . & . & . & 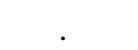 & $12369 \mathrm{~b}$ & $147336 \mathrm{~b}$ \\
\hline & naatit & $9.8 \mathrm{~b}$ & $650 *$ & $239 \mathrm{~b}$ & $148 \mathrm{~b}$ & 6740 & 70094 & & $11.8 \mathrm{~b}$ & $650 *$ & $245 \mathrm{~b}$ & 155 bce & 4732 & 49893 \\
\hline & juuret & $14.7 \mathrm{c}$ & $820 *$ & 112 c & $87 \mathrm{c}$ & 9056 & 116820 & & $15.9 \mathrm{c}$ & $820 *$ & $85 \mathrm{c}$ & 81 a & 7549 & 98224 \\
\hline 3 & Hirssi & $13.8 \mathrm{c}$ & $643 \mathrm{~b}$ & $580 \mathrm{~d}$ & $133 a b$ & $4745 \mathrm{c}$ & $47287 \mathrm{c}$ & 3 & $15.7 \mathrm{a}$ & 646 a & $580 \mathrm{~d}$ & 168 се & 3796 c & 37585 c \\
\hline 4 & Rehurapsi & $15.3 \mathrm{c}$ & $746 \mathrm{c}$ & $235 \mathrm{~b}$ & 153 bd & 9684 a & 111877 a & 4 & $17.4 \mathrm{a}$ & $721 \mathrm{~b}$ & $282 \mathrm{ab}$ & 126 bcd & 10847 bde & $120714 \mathrm{e}$ \\
\hline 5 & $\begin{array}{l}\text { Härkäpapu 70:30 } \\
\text { Härkäpapu 50:50 }\end{array}$ & $26.0 \mathrm{~d}$ & $706 \mathrm{~d}$ & 337 a & $184 \mathrm{e}$ & $7952 \mathrm{~d}$ & 86999 d & 5 & $23.4 \mathrm{c}$ & 659 a & $451 \mathrm{e}$ & $174 \mathrm{e}$ & 11018 be & $\begin{array}{c}112565 \text { de } \\
105588\end{array}$ \\
\hline 6 & & $27.5 \mathrm{e}$ & $700 \mathrm{~d}$ & $381 \mathrm{e}$ & 170 de & $7526 \mathrm{~d}$ & 81607 d & 6 & $23.2 \mathrm{c}$ & $672 \mathrm{a}$ & $461 \mathrm{e}$ & 163 се & 10140 ade & ade \\
\hline \multirow[t]{4}{*}{7} & Sinilupiini ** & $91.2 \mathrm{f}$ & 870 e & $250 \mathrm{~b}$ & $294 \mathrm{f}$ & 2152 e & 29011 e & 7 & $30.9 \mathrm{~d}$ & $674 \mathrm{a}$ & $480 \mathrm{e}$ & $98 \mathrm{ad}$ & 9269 ad & 96484 ad \\
\hline & & & & & & & & 8 & $21.2 \mathrm{c}$ & $650 \mathrm{a}$ & $459 \mathrm{e}$ & $182 \mathrm{e}$ & 11463 be & 115594 de \\
\hline & SEM & 0,64 & 7,4 & 12,5 & 7,1 & 452,4 & 5179,5 & & 1,10 & 12,5 & 23,3 & 15,6 & 605,2 & 6820,4 \\
\hline & Til. merkitsevyys & $* * *$ & $* * *$ & $* * *$ & $* * *$ & $* * *$ & $* * *$ & & $* * *$ & $*$ & $* * *$ & $* * *$ & $* * *$ & $* * *$ \\
\hline
\end{tabular}

Saman sarakkeen luvut eivät eroa toisistaan, jos ne on merkitty samalla kirjaimella (Tukey). * D-arvot rehutaulukosta. ${ }^{* *}$ Siemensato 
Valkuaispitoisuus vaihteli välillä 103-163 g/kg ka. Myös sulavuudet vaihtelivat runsaasti koepaikkojen välillä.

\section{Lupiinit}

Lupiineista testattiin vuonna 2010 Sonat -sinilupiinia, josta puitiin siemensato. Maaningalla kasvi kärsi selvästi kuivuudesta ja tuotti satoa hieman alle $1000 \mathrm{ka} \mathrm{kg/ha.} \mathrm{Ruukissa} \mathrm{satotaso} \mathrm{nousi} \mathrm{hieman}$ yli 2000 kiloon. Valkuaispitoisuus oli molemmilla koepaikoilla noin 300 g/kg ka.

Vuonna 2011 testattiin Lucid -valkolupiinia ja Trappe -vehnäseosta, joka korjattiin kokoviljana. Seokseen kylvettiin $30 \%$ vehnän täystiheydestä $\left(650 \mathrm{kpl} / \mathrm{m}^{2}\right)$ ja lupiinia $70 \%$ kasvin täystiheydestä $\left(70 \mathrm{kpl} / \mathrm{m}^{2}\right)$. Satoa seoksesta korjattiin Maaningalla $3700 \mathrm{ka} \mathrm{kg/ha} \mathrm{ja} \mathrm{Ruukissa} 9300$ ka kg/ha.

Lupiini-vehnä massan D-arvo oli Maaningalla noin $560 \mathrm{~g} / \mathrm{kg}$ ka. Ruukissa kasvusto oli lehtevämpää ja D-arvo oli yli 670 g/kg ka. Energiasato oli keskimäärin 60000 MJ/ha.

\section{Härkäpapu-vehnä}

Härkäpapu-vehnä -seoksessa sääolojen lisäksi lajikevalinta ja korjuuajankohta vaikuttivat tulokseen, mutta erot eivät olleet tilastollisesti merkitseviä. Seokset osoittautuivat varmoiksi sadontuottajiksi, keskimäärin niistä saatiin 8600 ka kg hehtaarilta. Kontu -härkäpapu :Trappe -vehnä -seos, joka kylvettiin 70:30 siemensuhteella (70 \% härkäpavun täystiheydestä / 30 \% vehnän täystiheydestä,) tuotti keskimäärin vain noin 200 kg ka enemmän satoa hehtaarilta, kuin 50:50 -seossuhteessa kylvetty. Kokeessa ei saatu merkitsevää eroa eri kylvömääräsuhteilla kylvettyjen koejäsenten kuiva-ainesatoihin.

Valkuaispitoisuus oli 50:50 kylvetyllä härkäpapu-vehnä -seoksella noin 150 g/kg ka ja se nousi noin 10 g/kg ka, kun härkäpapua kylvettiin 20 \% enemmän. Erot eri kylvömäärillä kylvettyjen massojen raakavalkuaispitoisuuteen eivät kuitenkaan olleet tilastollisesti merkitsevä. Siemenseos-suhde 70:30 valittiin kokeeseen, koska vastaavaa suhdetta oli käytetty Ruotsin Maatalousyliopiston kokeissa Uumajassa (Haag 2007).

Vuonna 2011 koesarjassa testattiin myös Kontu -härkäpapua myöhäisempää Fuego -lajiketta, joka kylvettiin Trappe -vehnän kanssa 70:30 suhteessa. Fuego -lajike kasvoi pituutta noin $10 \mathrm{~cm}$ Kontua enemmän, mutta Fuego- seoksen sadot eivät eronneet Kontu -lajikkeen tuottamasta määrästä merkitsevästi. Koska kaikki härkäpavut korjattiin samaan aikaan, ei Fuego -härkäpavun massan myöhäisemmästä kehityksestä tiedetä. Korjattaessa Fuego -kasvustot olivat kuitenkin elinvoimaiset, joka tukee teoriaa, että myöhäisempi härkäpapulajike voisi olla soveltuvampi kokoviljamassan tuotantoon.

Korjuuajankohtaa ei tutkittu kokeessa, mutta Uumajassa (Haag 2007) toteutetuissa kokeissa on todettu myöhäisemmän korjuuajankohdan lisäävän kuiva-ainesatoa. Kokeessa todettiin optimaaliseksi korjuuajankohdaksi hetki, jolloin 100 \% härkäpavun paloista on saavuttanut täyden pituutensa ja ne ovat täyttyneet. Ajankohtana massan raakavalkuaispitoisuus oli noin 160 g/kg ka. Tässä esitetyt tulokset, erityisesti vuosi 2010, näyttäisi tukevan ruotsalaisten (Haag 2007) teoriaa, jossa raakavalkuainen lisääntyy kasvukauden edetessä siementen täyttymisen myötä. Näyttäisi siltä, että kypsyessään härkäpapu -massa käyttäytyy samoin kuin kokoviljasäilörehu: vaikka korren kuitupitoisuus lisääntyy tuleentumisen edetessä, ei massan sulavuus kuitenkaan laske, koska siementen suhteellinen osuus kasvaa. Härkäpapu -säilörehun korjuuajankohtaa ei kuitenkaan voi siirtää liikaa, sillä palkojen varisemistappiot korjuun aikana alentavat nopeasti massan rehuarvoa.

Härkäpapukasvustojen energia-arvot on laskettu rehutaulukon (MTT 2011) perusteella. Maaningalla energiasato oli yli 70000 MJ/ha, Ruukissa päästiin vuonna 2010 yli 80000 MJ/ha ja 2011 jopa yli $100000 \mathrm{MJ} /$ ha energiasatoihin. Luvut ovat suuntaa antavia, sillä käytännön kokemuksien perusteella lehmät ovat lypsäneet hyvin härkäpapu-vilja -säilörehulla ja tuntuma on, että sulavuudet ja siten myös energia-arvot voisivat olla laskennallisia arvoja korkeammat (Juutinen 2011). Tällä hetkellä on vaikea arvioida härkäpapuseosten tarkkoja energia-arvoja, koska härkäpapusäilörehun sulavuuskokeita ei ole tehty pohjoismaissa eikä rehulaboratorioiden menetelmiä ole voitu kalibroida todelliseen in vivo -sulavuuteen.

\section{Johtopäätökset}

Rehukaalilla, -rapsilla ja varsinkin rehujuurikkaalla on mahdollisuus tuottaa korkeita kuiva-aine- ja energiasatoja. Kasvustojen hyödyntäminen on kuitenkin ongelmallista, sillä toimivaa korjuuketjua rehujuurikkaan korjaamiseksi ei ole markkinoilla. Rehukaali ja -rapsi olisi mahdollista korjata säilörehuksi nurmisäilörehun tapaan, mutta korkea kosteuspitoisuus vaikeuttaa säilöntää ja lisää erittyvän 
puristenesteen määrää. Potentiaalisin vaihtoehto näiden kasvien hyödyntämiselle onkin syyslaidunnus. Laidunkauden pidentäminen tuo kustannussäästöjä eläinten ruokintaan, mutta toisaalta syksyn kosteat olosuhteet asettavat omat reunaehtonsa laajamittaiselle laidunnukselle.

Härkäpapu-vehnä -seos osoittautui potentiaaliseksi ja satovarmaksi kokoviljasäilörehun raakaaineeksi. Jatkossa olisi ensiarvoisen tärkeää kehittää luotettavat rehuarvonmääritysmenetelmät palkokasvi-viljaseoskasvustoista korjatuille säilörehuille.

Hirssin rehuviljelyä ei voi tulosten perusteella suositella Keski- ja Pohjois-Suomen olosuhteissa. Valkolupiini saattaisi sen sijaan olla eräs potentiaalinen vaihtoehto viljan seoskasviksi kokoviljasäilörehukasvustoon. Tässä tutkimuksessa valkolupiini oli kuitenkin mukana vain yhtenä koevuonna, joten luotettavaa tietoa sen satoisuudesta ja rehun laadusta Keski- ja Pohjois-Suomen olosuhteissa ei vielä saatu.

\section{Kirjallisuus}

Bartholomew, H.M. 2011. Brassicas for forage. [verkkojulkaisu]. Ohio State University. [Viitattu 12.12.2011]. Saatavana internetistä: http://ohioline.osu.edu/agf-fact/0020.html

Haag, T. 2007. Åkerböna i samodling med vårvete som helgrödesensilage till mjölkkor. Department of Agricultural research for Northern Sweden, SLU. Röbäcksdalen meddelar vol. 3:2007.

Joki-Tokola, E. 2002. Kokoviljasäilörehu nautakarjatilan karkearehuruokinnan vaihtoehtona. Teoksessa: toim. Eeva Saarisalo ja Mari Topi-Hulmi. Rehuvaihtoehtoja nautakarjatiloille. Suomen Nurmiyhdistyksen julkaisu 18: 5-11.

Joki-Tokola, E. 2003a. Viljelytekniikka. Teoksessa: Kyllikki Lampinen, Taina Harmoinen, Hanne Teräväinen (toim.). Kokoviljasäilörehun tuotanto ja käyttö. Maaseutukeskusten Liiton julkaisuja 993: Tieto tuottamaan 102: $16-25$.

Joki-Tokola, E. 2003b. Korjuu, säilöntä ja varastointi: kokoviljan korjuu. Teoksessa: Kyllikki Lampinen, Taina Harmoinen, Hanne Teräväinen (toim.) . Kokoviljasäilörehun tuotanto ja käyttö. Maaseutukeskusten Liiton julkaisuja 993: Tieto tuottamaan 102: 29-31.

Joki-Tokola, E., Huuskonen, A., Huttu, S. \& Kiljala, J. 2002a. Rehuvirna lihanautojen kokoviljasäilörehuruokinnassa. Teoksessa: Maataloustieteen Päivät 2002: Kotieläintiede. Maaseutukeskusten Liiton julkaisuja 977: s. 196-199.

Joki-Tokola, E., Huuskonen, A. \& Kiljala, J. 2002. Ruisvirna kasvavien sonnien kokoviljasäilörehuruokinnassa. Teoksessa: toim. Eeva Saarisalo ja Mari Topi-Hulmi. Rehuvaihtoehtoja nautakarjatiloille. Suomen Nurmiyhdistyksen julkaisu 18: 87-94.

Juutinen, E. 2011. Säilörehua herneestä ja härkäpavusta. Nauta 41, 4: 34-35.

Kiljala, J., Isolahti, M., Huuskonen, A. \& Joki-Tokola, E. 2004. Palkoviljat kokoviljasäilörehun raakaaineena. In: Toim. Anneli Hopponen ja Marketta Rinne. Maataloustieteen Päivät 2004, 12.-13.1.2004 Viikki, Helsinki [: esitelmät ja posterit]. Suomen maataloustieteellisen seuran tiedote 19: $4 \mathrm{~s}$.

Lehto, E. \& Joki-Tokola, E. 1999. Kauran ja rehuvirnan seoskasvuston korjuu säilörehuksi. Koetoiminta ja käytäntö 56, 4 (22.6.1999): 2.

Manninen, M., Nykänen, A. \& Musikka, T. 2004. Vehnä-rehuvirnakokoviljasäilörehua lihahiehoille. Käytännön maamies 11: 46-48.

MTT. 2011. Rehutaulukot ja ruokintasuositukset. Verkkopalvelu. Saatavilla internetistä: https://portal.mtt.fi/portal/page/portal/Rehutaulukot

Nykänen, A. \& Jauhiainen, L. 2010. Herneillä ja virnoilla typpiomavaraisuutta kokoviljatuotantoon. Teoksessa: Toim. Anneli Hopponen. Maataloustieteen Päivät 2010, 12.-13.1.2010 Viikki, Helsinki: esitelmät ja posterit. Suomen maataloustieteellisen seuran tiedote 26: $5 \mathrm{~s}$.

Nykänen, A., Rinne, M. \& Jauhiainen, L. 2010. Palkokasveista valkuaista ja sulavuutta kokoviljaseoksiin. Teoksessa: Toim. Anneli Hopponen. Maataloustieteen Päivät 2010, 12.-13.1.2010 Viikki, Helsinki: esitelmät, posterit. Suomen maataloustieteellisen seuran tiedote 26: $7 \mathrm{~s}$. 